\title{
ОРХОНЫ ХӨНДИЙН БАЙГАЛИЙН ЦОГЦОЛБОРТ ГАЗРЫН УРГАМАЛЖИЛТЫН СУДАЛГАА (ХАРХОРИН СУМЫН ЖИШЭЭН ДЭЭР)
}

\author{
Д.Эрдэнэчимэг, О.Бүрэнжаргал \\ Экологи технологи хөгжлийн сургууль \\ chimgee15davaa@yahoo.com
}

\section{ХУРААНГУЙ}

Орхоны хөндийн байгалийн иогиолборт газрын ургамлан бүлгэмдлийн судалгааг Хархорин сумын жишээн дээр Мойлт, Намаг, Их элстий, Баянзүрх зэрэг газруудад хийж гүйцэтгэв. Судалгааны явиад ургамлын зүйлийн бүрэлдэхүүн, тусгаг бүрхэи, ургаи зэрэг үзүүлэлтийг тодорхойлж бэлчээрийн доройтлын байдалд үнэлгээ өгөв. Судалгааны үр дүнгээр төв суурин газарт ойр орших Мойлтын амны бэлчээр хүчтэй талхлагдсан байсан бол сумын төвөөс харьиангуй хол зайд орших Намаг, Их Элстийн бэлчээр дунд зэрэг талхлагдсан, харин Баянзурхийн бэлчээр бага ашиглагдсан буюу соргог бэлчээрт хамаарч байна.

ТYЛХYУР ҮГ: ургамлан бүлгэмдэл, бэлчээрийн доройтол, ургац, тусгаг бүрхэц, зүйлийн бүрэлдэхүүн

\section{ОРШИЛ}

Орхоны хөндийн байгалийн цогцолборт газрын хамгаалалтын захиргаa нь Архангай аймгийн Хотонт, Хашаат, Өвөрхангай аймгийн Хархорин, Хужирт, Бат-Өлзий, Уянга сумдын 363636 га талбайг хариуцан хамгаалж ажилладаг. Үүнээс Хархорин сум нь 12813 хүн амтай, 3569 өрхтэй, Орхон багт малчин өрх 208, нийт малын тоо 27000, Нарийн хүр багийн нутагт малчин өрх 129, нийт малын тоо 24839 тус тус байдаг ба хязгаарлалтын бүсэд мал аж ахуй эрхлэн жилийн дөрвөн улиралд бэлчээрийг ашиглаж байгаa учраас ургамлын зүйлийн бүрэлдэхүүн, бүрхэц, арви хэрхэн өөрчлөгдөж байгааг судлах шаардлага гарч байна. Уг судалгааны ажлыг хийснээр хамгаалалтын захиргаa нь бэлчээрийн ургамлан бүлгэмдлийн өөрчлөлтийн талаарх судалгааны эх материалтай болж тухайн нутагт тархаж байгаa ан амьтан болон малын тоо толгойг зохицуулахад оршино. 


\section{СУДАЛГААНЫ ЗОРИЛГО, ЗОРИЛТ}

Энэхүү судалгааны ажлын зорилго нь Орхоны хөндийн байгалийн цогцолборт газрын Хархорин Мойлт, Баянзүрх, Намаг, Их Элстий зэрэг газруудын ургамлан бүлгэмдлийн бүтэц, бүрэлдэхүүнийг судлахад оршино.

Дээрх зорилгодоо хүрэхийн тулд дараах зорилтуудыг дэвшүүлж ажиллав.

1. Орхоны хөндийн байгалийн цогцолборт газрын ургамлан бүлгэмдлийн зүйлийн бүрэлдэхүүнийг тодорхойлох, зонхилох ашигт ургамлуудыг таних зурагт гарын авлага гаргах.

2. Ургамлан бүлгэмдлийн тусгаг бүрхэцийг тодорхойлох

3. Ургамлан бүлгэмдлийн ургацыг тодорхойлох

4. Баянзурх, Намаг, Их элстий, Мойлт зэрэг газруудын бэлчээрийн доройтлын зэргийг үнэлэх

\section{СУДАЛГААНЫ ХЭРЭГЛЭГДЭХУУН, АРГА ЗУЙ}

Ургамлын судалгааг Орхоны хөндийн БЦГ болох Хархорин суман дахь Баянзүрх, Намаг, Их элстий, Мойлт зэрэг газруудад 2013 оны 7сарын 17 наас 25 нь , 8-р сарын 17 аас 25 ны хооронд хийж гүйцэтгэсэн болно.

1. Баянзүрх, Намаг, Их элстий, Мойлт зэрэг газарт 4 цэг сонгон авч 1 м $^{2}$ талбайд 6 давталттайгаар зүйлийн бүрэлдэхүүнийг тодорхойлсон ба гадна талбайд тохиолдох ургамлуудыг бүртгэж латин нэрийг И.В.Грубовын (1982) бүтээлд зааснаар авав.

2. Ургамлын тусгаг бүрхцийг Раменскийн тор ашиглан бүлгэмдэл тус бүрд 6 давталттайгаар тодорхойлов.

3. Судалгааны талбай бүрд ургацын дээжийг 1 $\mathrm{m}^{2}$ талбайгаас 6 давталттайгаар зүйлээр нь ялган газрын хөрсийг шүргүүлэн хайчлан авч, цаасан уутанд хийж хатаагаад, электрон жин ашиглан агаарын хуурай жинг граммаар илэрхийлэн гаргасан ба нэг га талбайн ургацыг кг-д шилжүүлэн гаргав.

4. Бэлчээрийн доройтлын зэрэглэлийг С.Жигжидсүрэнгийн (2005) ангиллаар үнэлэв.

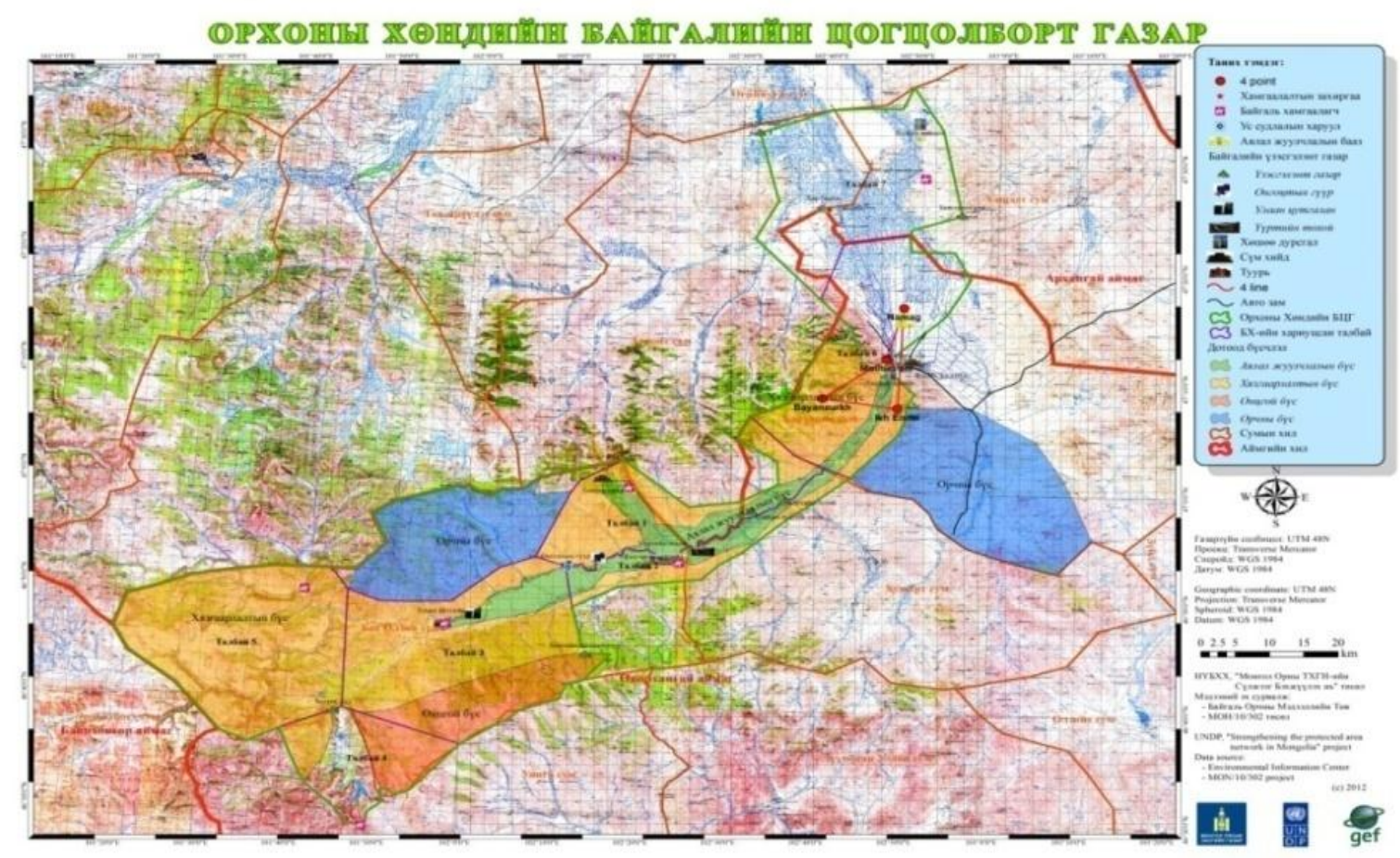

1-р зураг. Судалгааны талбайнууд 


\section{СУДАЛГААНЫ ҮР ДҮН}

\section{Ургамлан бүлгэмдлийн хэв шинж}

Судалгааны цэг 1. Мойлтын ам. Хархорин сумын төвөөс 4 км-т оршино. Жилийн дөрөв улиралд бэлчээрт их ашиглагддаг, ургамалжилт сийрэг хэдий ч судалгаа явуулсан хугацаанд хур бороо сайн орсон байсан тул ургамал ургах таатай орчин бүрдсэн байлаа. Уг бүлгэмдэлд 7-p сард 15 овгийн 24 төрөлд хамаарах 31 зүйл ургамал бүртгэгдсэн бол 8-р сард 18 овгийн 27 төрөлд хамрах 38 зүйл ургамал болон нэмэгдсэн. Судалгааны цэг 2. Намаг нь сумын төвөөс 22 км-т оршино. Жилийн дөрвөн улиралд бэлчээрт их ашиглагддаг хэдий ч чийгийн хангамж сайн тул ургамалжилт харьцангуй өтгөн шигүү байв. Энд 21 овгийн 25 төрөлд хамаарах 29 зүйл ургамал бүртгэгдсэн /7 сарын байдлаар/.

Харин 8-р сард 23 овгийн 29 төрөлд хамаарах 32 зүйлийн ургамал болон өөрчлөгдсөн.
Судалгааны цэг 3. Их элстий нь сумын төвөөс 19 км-т оршино. Хавар, зун, намрын улиралд бэлчээрт ашиглагддаг, ургамалжилт сийрэгдүY ба 20 овгийн 45 төрөлд хамаарах 48 зүйл ургамал бүртгэгдсэн 7 сарын байдлаар/ .

Судалгааны дараагийн хугацаанд 24 овгийн 48 төрөлд хамаарах 57 зүйл ургамал бүртгэгдсэн байлаа /8 сарын байдлаар/.

Судалгааны цэг 4. Баянзүрх нь сумын төвөөс 28 км-т орших ба зөвхөн өвлийн улиралд бэлчээрт ашигладаг тул ургамалжилт маш шигүүөтгөн ургасан байлаа. Энэ бүлгэмдэлд 28 овгийн 65 төрөлд хамаарах 80 зүйл ургамал бүртгэгдсэн /7 сарын байдлаар/ бол 8-р сард 30 овгийн 70 төрөлд хамаарах 85 зүйл ургамал бүртгэгдсэн байв.

Хүснэгт 1

Судалгааны талбайнууд дахь ургамлын зүйлийн бүрэлдэхүүн

\begin{tabular}{|c|c|c|c|c|c|c|c|c|c|}
\hline \multirow{2}{*}{ № } & \multirow{2}{*}{ Газрын нэр } & \multicolumn{3}{|c|}{7 сард } & \multirow{2}{*}{$\begin{array}{c}1 \mathrm{~m}^{2} \text { дахь } \\
\text { зүйлийн } \\
\text { тоо, ш }\end{array}$} & \multicolumn{3}{|c|}{8 сард } & \multirow{2}{*}{$\begin{array}{c}1 \mathrm{~m}^{2} \text { дахь } \\
\text { зүйлийн тоо, ш }\end{array}$} \\
\hline & & Овог & Төрөл & Зүйл & & Овог & Төрөл & Зүйл & \\
\hline 1 & Мойлт & 15 & 24 & 31 & 8 & 18 & 27 & 38 & 5 \\
\hline 2 & Намаг & 21 & 25 & 29 & 10 & 23 & 29 & 31 & 11 \\
\hline 3 & Их Элстий & 20 & 45 & 48 & 12 & 24 & 48 & 57 & 9 \\
\hline 4 & Баянзүрх & 28 & 65 & 80 & 15 & 30 & 70 & 85 & 17 \\
\hline
\end{tabular}

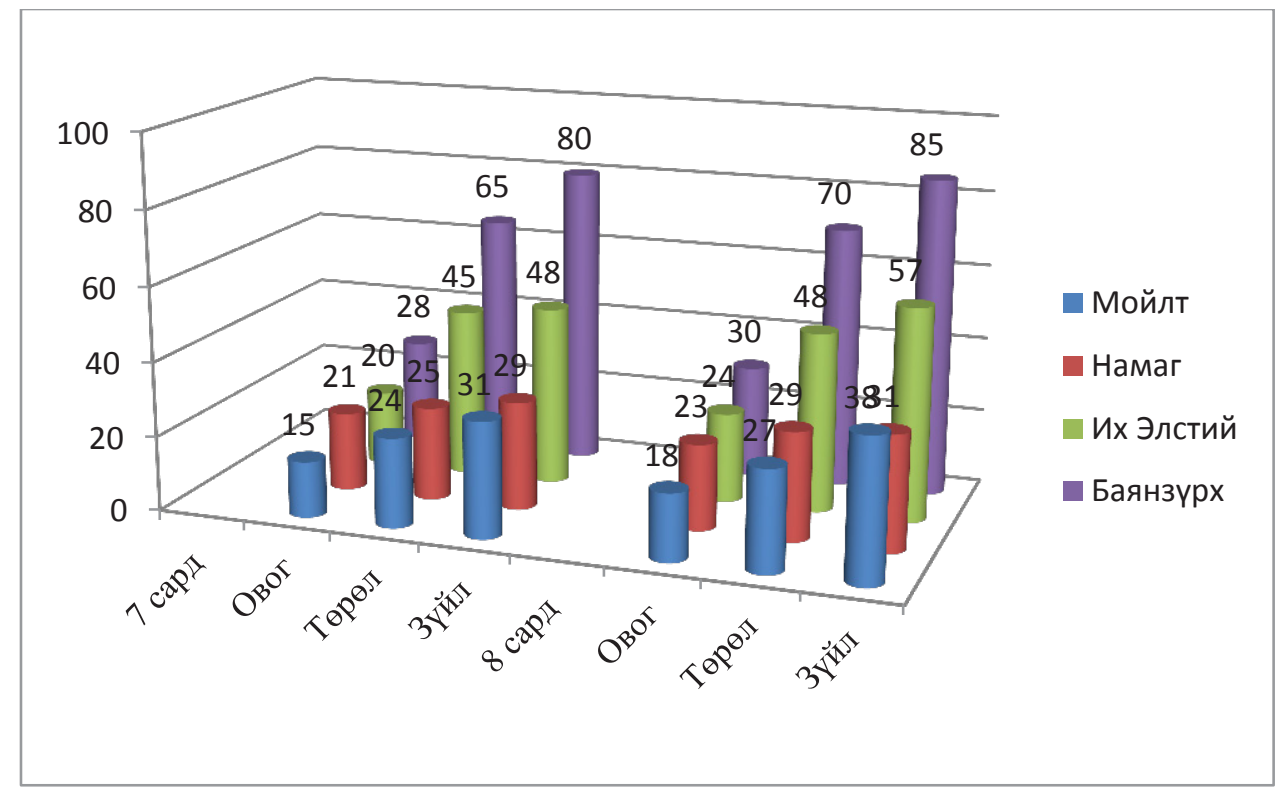

2-р зураг. Ургамлын зүйлийн бүрэлдэхүүн 7, 8 дугаар сарыг харьцуулсан байдал 
Бүлгэмдэл дэх ургамлуудын аж ахуйн бүлэг

Хүснэгт 2

\begin{tabular}{clcccccc}
\hline \multirow{2}{*}{ o } & Газрын нэр & $\begin{array}{c}\text { Нийт } \\
\text { зүйл }\end{array}$ & $\begin{array}{c}\text { Алаг } \\
\text { өвс }\end{array}$ & Үетэн & Сөөг & Улалж & Буурцагтан \\
\hline 1 & Мойлт & 38 & 27 & 5 & 1 & 1 & 2 \\
2 & Намаг & 31 & 24 & 3 & 0 & 1 & 3 \\
3 & Ихэлстий & 57 & 32 & 15 & 1 & 1 & 8 \\
4 & Баянзүрх & 85 & 59 & 5 & 12 & 2 & 7 \\
\hline
\end{tabular}

Ургамлан бүлгэмдлийн тусгаг бүрхэц. Судалгаа явуулсан эхний үе буюу 7-р сард Мойлтын амны шарилж-улалжит бүлгэмдэлд ногоон ургамлын бүрхэц $35 \%$, хагд өвсний бүрхэц 8\%, ургамалгүй хоосон газар 57\%-ийг эзлэж байв (График 3). Ногоон ургамлын бүрхэцийн зонхилох хувийг Artemisia adamsii, Carex duriuscula эзлэж, Stipa krylovii, Agropyron cristatum, Cleistogenes squarrosa зэрэг ургамлууд дэд зонхилогчийн үүрэг гүйцэтгэнэ. Үүнээс харвал ашиглалт ихтэй бүлгэмдэлд бэлчээрлэлтийн нөлөөг сайн тэсвэрлэдэг, талхлагдлын индикатор ургамлууд (Artemisia adamsii, Carex duriuscula, Cleistogenes squarrosa) ихэнх хувийг бүрдүүлж байна.
Харин 8-р сард тус бүлгэмдлийн ногоон ургамлын бүрхэц өмнөх сарынхаас 2\%-иар нэмэгдсэн бол хагд өвсний бүрхэц 2\%-иар буурсан үзүүлэлттэй гарсан.

Их Элстийн үетэн-алаг өвст бүлгэмдлийн хувьд 7-p сард ногоон ургамлын бүрхэц 52\%, хагд өвс $8 \%$, ургамалгүй хоосон газар $40 \%$ байсан бол 8 -р сард ногоон ургамлын бүрхэц $60 \%$, хагд өвс $4 \%$, ургамалгүй хоосон газар $36 \%$ болон өөрчлөгдсөн (График 3). Ногоон ургамлын тусгаг бүрхцийн зонхилох хувийг Stipa krylovii, Agropyron cristatum зэрэг ургамлууд эзлэж, Cleistogenes squarrosa, Elymus chinensis, Artemisia frigida, Cymbaria dahurica, Heteropappus hispidus зэрэг ургамлууд дэд зонхилогчийн үүрэг гүйцэтгэнэ.

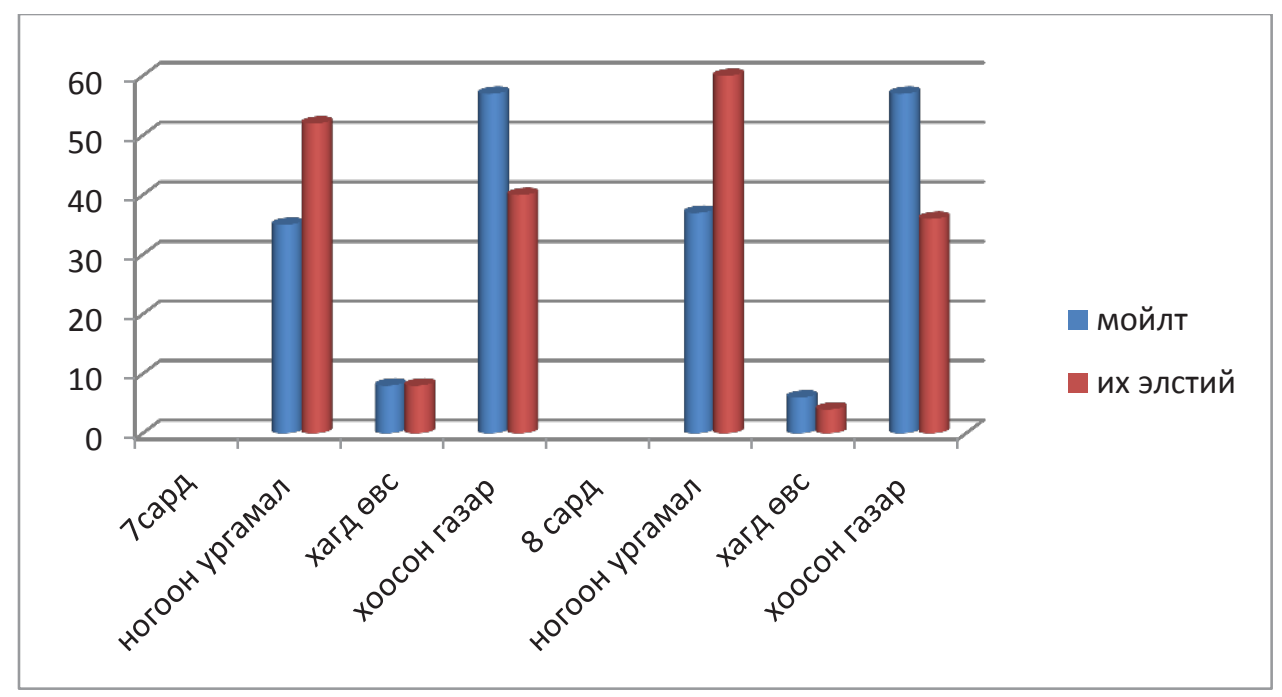

3-р зураг. Мойлт, Их Элстий нь уулын хээрийн бүсийн ургамлын тусгаг бүрхэц харьцуулсан үзүүлэлт

Судалгааны дараагийн талбай болох Баянзүрхийн амны алаг өвс-үетэнт бүлгэмдэлд 7сарын ногоон ургамлын бүрхэц нь, 90\%, харин 8 сард бас ногоон ургамлын бүрхэц 90\%, хагд өвсний бүрхэц 10\% (График 2) байсан ба ногоон ургамлын тусгаг бүрхцийн зонхилох хувийг алаг өвс Geranium pratense, Phlomis tuberose, Trollius asiaticus, Trifolium lupinaster, Vicia ameona зэрэг ургамлууд эзлэж, Alopecurus pratensis, Poa attenuatha, Puccinellia tenuiflora зэрэг ургамлууд дэд зонхилогчийн үүрэг гүйцэтгэнэ.
Харин Намаг буюу нугын хэвшинжийг төлөөлөх улалж-үетэнт бүлгэмдэлд 7-р сард нийт ногоон ургамлын бүрхэц 70\%, хагд өвсний бүрхэц 5\%, ургамалгүй хоосон газар 25\% байсан бол 8-p сард ногоон ургамлын бүрхэц 79\%, хагд өвс 2\%, ургамалгүй хоосон газар 19\% болон өөрчлөгдсөн (График 3). Ногоон ургамлын тусгаг бүрхцийн зонхилох хувийг Agrostis Trinii, Poa attenuatha, Elytrigia repens, Puccinellia tenuiflora, Carex duriuscula зэрэг ургамлууд зонхилогч болон дэд зонхилогчийн үүрэг гүйцэтгэнэ. 
Харин 8-р сард тус бүлгэмдлийн ногоон нэмэгдсэн бол хагд өвсний бүрхэц 3\%-иар ургамлын бүрхэц өмнөх сарынхаас 9\%-иар буурсан үзүүлэлттэй гарсан.

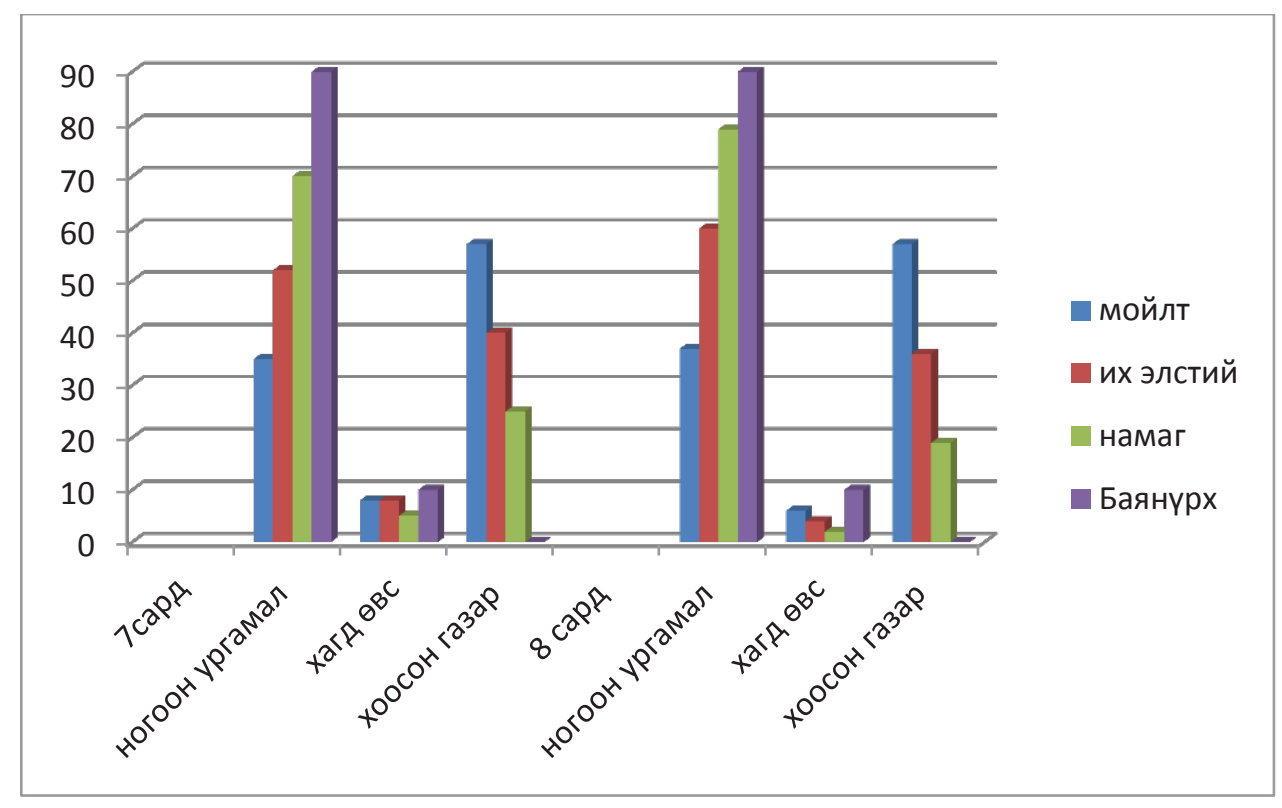

4-р зураг. Ургамлан бүлгэмдлийн ургац /кг/га/

\section{Ургамлан бүлгэмдлийн ургацыг кг/га-д}

Бэлчээрийг зөв зохистой ашиглах, түүний тэжээлийн нөөцийг хуваарьтай зарцуулах, бэлтгэх өвс тэжээлийнхээ хэмжээг урьдчилан тооцоход бэлчээр хадлангийн ургацыг мэдэх зайлшгүй шаардлагатай. Мойлтын амны шарилж-улалжит бүлгэмдлийн нийт ургац нь 7-н сарын байдлаар 380 кг/га байсны ихэнх хувийг Artemisia adamsii, Carex duriuscula эзэлж байсан ба харин 8-р сард ургацын хэмжээ ижил байв (График 3).

Их элстийн үетэн-алаг өвст бүлгэмдлийн нийт ургац нь 7 сарын байдлаар 360 кг/га байсны ихэнх нь Stipa krylovii, Artemisia frigida, Elymus chinensis, Carex duriuscula, Potentilla acaulis зэрэг ургамлууд эзэлж байлаа.Харин 8-р сард ургац нь $1 \%$ aар буурсан Үзүүлэлтэй харагдаж байна (График 3).

\section{График-3 Мойлт, Их Элстий нь уулын хээрийн бүсийн ургамлын ургац /кг/2а/}

График-4.

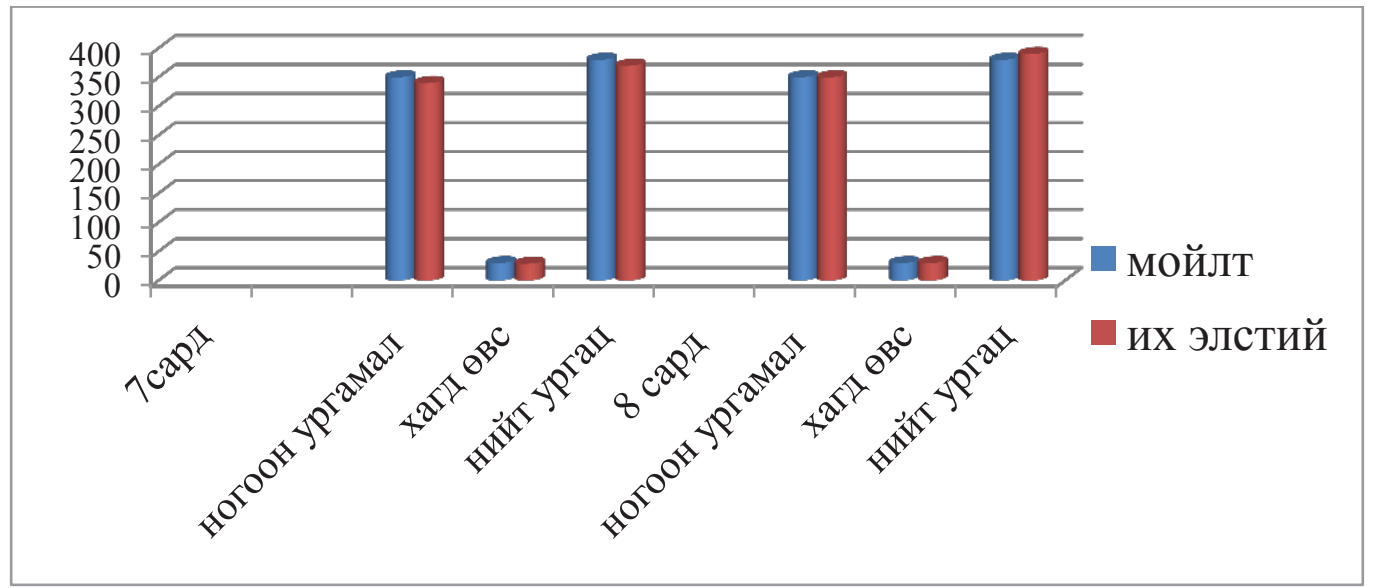

Намагт улалж-үетэнт бүлгэмдлийн нийт ургац нь 7 сард 460 кг/га байсны ихэнх Agrostis Trinii, Poa attenuatha, Elytrigia repens, Puccinellia tenuiflora, Carex duriuscula зэрэг ургамлууд эзэлж байлаа. Харин 8-р сард ургац нь $1.1 \%$ аар өссөн үзүүлэлттэй харагдаж байна (График 5). 
Баянзүрхийн алаг өвс-үетэнт бүлгэмдлийн нийт ургац нь 7 сард 640 кг/га байсан харин 8 сарын нийт ургац нь Үүнээс 2\%-р кг/га аар өссөн Үзүүлэлттэй гарсан . (График 5).

\section{Ургамлан бүлгэмдлийн ургац /кг/га/}

График-5.

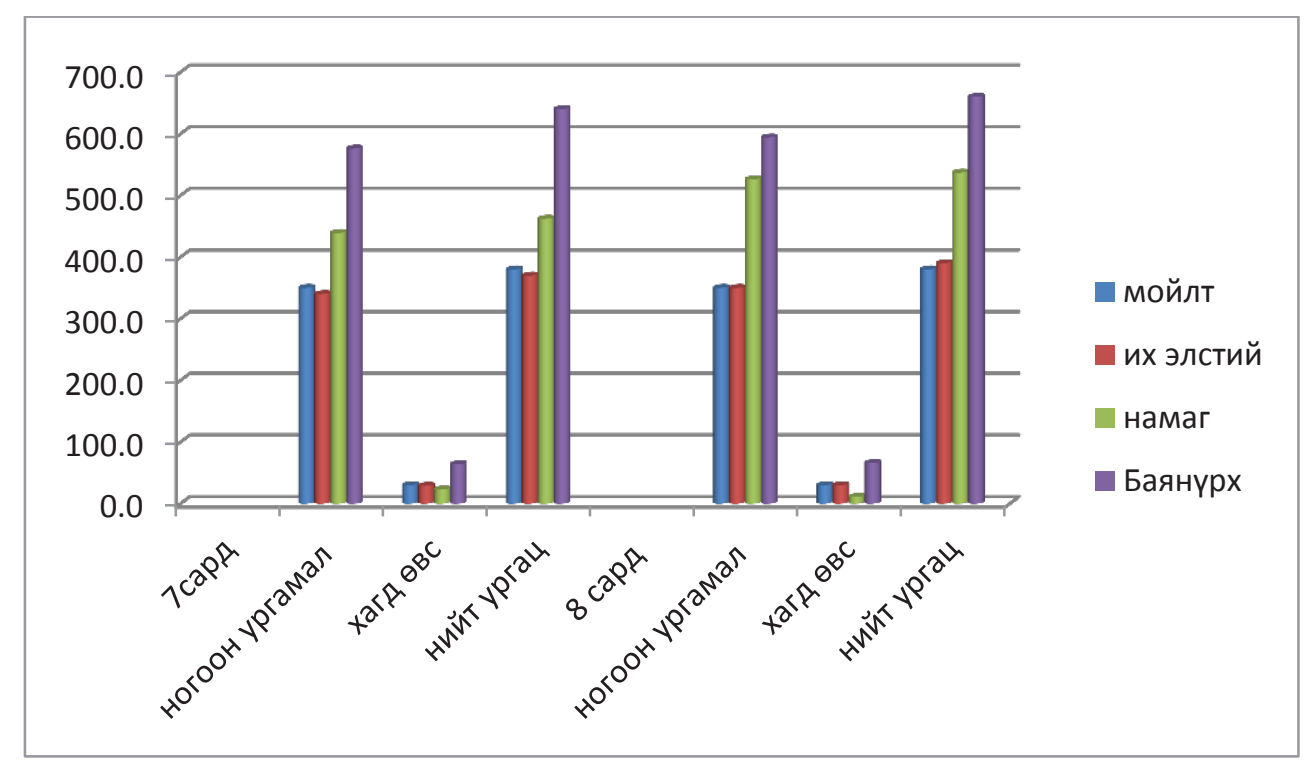

\section{ШУУН ХЭЛЭЛЦЭХУЙ}

Бэлчээр ашиглалт, талхагдах үйл явц нь нэг талаас хүн малын хүчин зүйлийн нөлөөнөөс болж, амьдралын эх үүсвэр болсон худаг, усны асуудал, түүний хомсдолоос болоод мал аж ахуй эрхэлдэг малчин өрх жилийн дөрвөн улиралд нэг газраа нутагладаг болсонтой холбоотойгоор байгалийн бэлчээрийн ургамлын бүтэц бүрэлдэхүүн өөрчлөгдөж доройтолд орж байна.

Тусгай хамгаалалттай газар нутгийн сүлжээг бэхжүүлэх нь төслийн захиалгаар 2011 онд хийсэн судалгааны үр дүнгээр Орхоны хөндийн байгалийн цогцолборт газрын Хархорин, Хужирт, Хашаат, Хотонт сумдын нийт 6-н багийн нутаг дэвсгэрт бэлчээрийн үнэлгээгээр нийт 154,646 га бэлчээрийн 10\% нь хэвийн буюу бага зэрэг доройтсон, $38 \%$ нь дунд зэрэг, $52 \%$ нь хүчтэй доройтсон зэрэглэлд хамаарч байсан байна. Бидний судалгаа нь Орхоны хөндийн Байгалийн цогцолборт газрын Хархорин сумын Орхон багийн Баянзүрх, Их Элстий, Нарийнхүр багийн Мойлт, Намаг зэрэг газрууд хамрагдсан ба судалгааны үр дүнгээр Мойлтын амны бэлчээр хүчтэй талхлагдсан, Намаг болон Их Элстийн бэлчээр дунд зэргийн талхлагдсан гэж үзэв. Харин Баянзүрхийн бэлчээрийг талхлагдаагүй буюу соргог бэлчээрт хамааруулсан болно.

\section{ДУГНЭЛТ}

1. Хархорин сумын Орхоны хөндийн байгалийн цогцолборт газрын зарим ашигт ургамлын зурагт лавлах гарын авлага гаргасан.

2. Ургамлан бүлгэмдлийн зүйлийн бүрэлдэхүүнийг тодорхойлоход нийт 40 овгийн 133 төрөлд хамаарах 165 зүйлийн ургамал бүртгэгдсэн.

3. Ургамлан бүлгэмдэлийн 7 сард Мойлт тусгаг бүрхэц нь $35 \%$ байсан бол 8 сард $37 \%$ болж $2 \%$-р өссөн харагдаж байна. Их элстий 7 сард

тусгаг бүрхэц нь 52\% байсан бол 8 сард $60 \%$ болж 8\%-р өссөн байна. Намаг 7 сард тусгаг бүрхэц нь 70\% байсан бол 8 сард $79 \%$ болж 9\%-р нэмэгдсэн байна.Харин Баянзүрхэд 7, 8p саруудад ургамлын тусгаг бүрхэц $90 \%$-тай байсан.

4. Ургамлан бүлгэмдлийн ургацыг тодорхойлоход Мойлтын ам 7 сар 8 саруудад ижил ургацтай 380 кг/га байв.харин Их Элстий эийт ургац 7 сард 360 кг/га басан бол 
8 сард ургацын хэмжээ 1 \%аaр өссөн Үзүүлэлттэй харагдаж байна.Намагын нийт ургац 7 сард 460кг/га байсан бол 8 сард $1,1 \%$ иар өссөн харагдаж байна Баянзүрхийн ам 7 сард 640 кг/га байсан бол 8 сард ургацын хэмжээ $2 \%$ иар өсөөн дүнтэй гарсан

5. Орхоны хөндийн байгалийн цогцолборт газрын Хархорин сумын Мойлт, Баянзүрх, Их элстий, Намаг зэрэг газруудын ургамлан бүлгэмдлийн бүтэц, бүрэлдэхүүн нь мал бэлчээрт ашиглагдсан байдлаас хамаарч бэлчээрийн доройтлын зэрэглэлийн хувьд харилцан адилгүй байна.

- Уулын хээрийн хэв шинж болох Мойлтын амны үетэн-алаг өвст ургамлан бүлгэмдэл нь жилийн дөрвөн улиралд бэлчээрт их ашиглагдсаны улмаас хүчтэй доройтож, шарилжулалжит бүлгэмдэл болон өөрчлөгдсөн байна.

\section{АШИГЛАСАН ХЭВЛЭЛ}

1. Болормаа Б., Булгамаа Д., Монгол орны гуурс дээд ургамлын хураангуйлсан нэрийн жагсаалт УБ 2012

2. Грубов. В.И. УБ1982 Монгол орны гуурст ургамал таних бичиг

3. Жигжидсүрэн.С, "Бэлчээрийн менежмент" УБ., 2005

4. Өлзийхутаг. Н.,"БНМАУ-ын бэлчээр, хадлан дахь тэжээлийн ургамал таних бичиг” УБ., 1985
- $\quad$ Баянзүрхийн ам буюу ойт хээрийн алаг өвс-үетэнт ургамлан бүлгэмдэл нь ургамлын зүйлийн бүрэлдэхүүн, тусгаг бүрхэц, ургац ихтэй соргог бэлчээрт хамаарна.

- Сумын төвөөс харьцангуй хол зайд орших Их Элстийн үетэн-алаг өвст бүлгэмдэл нь хавар, зун, намрын улиралд бэлчээрт ашиглагддаг хэдий ч Мойлтын амны ургамлан бүлгэмдэлтэй харьцуулахад энд зүйлийн бүрэлдэхүүн, ургамлын тусгаг бүрхэц, ургацын хэмжээ их байсан ба бэлчээр дунд зэрэг доройтсон байв.

Намаг буюу нугын улалж-үетэнт бүлгэмдэл нь жилийн дөрвөн улиралд бэлчээрт ашиглагддаг боловч чийгийн хангамж сайн тул ургамал богино хугацаанд нөхөн сэргэх боломжтой ба бэлчээрийн доройтлын хувьд дунд зэрэг талхлагдсан байна.

5. “Орхоны хөндийн байгалийн цогцолборт” газрын бэлчээрийн нөөц, даацын үнэлгээ судалгааны тайлан. УБ.2011

6. Орхоны хөндийн байгалийн цогцолборт газрын менежментийн төлөвлөгөө, УБ 2011

7. Чогний О. Монголын нүҮдлээр ашиглагдсан бэлчээрийн өөрчлөгдөх, сэргэх онцлог УБ 2001 